\title{
Subjects with local allergic rhinitis can be identified by basophil activation test
}

\author{
Paloma Campo ${ }^{1 *}$, Carmen Rondon', Enrique Gomez², Natalia Blanca-Lopez ${ }^{3}$, M Jose Torres ${ }^{1}$, Esther Barrionuevo ${ }^{1}$, \\ Rocio Herrera', Luisa Galindo', Cristobalina Mayorga ${ }^{2}$, Miguel Blancal' \\ From 9th Symposium of Experimental Rhinology and Immunology of the Nose (SERIN 2013) \\ Leuven, Belgium. 21-23 March 2013
}

\section{Background}

Local allergic rhinitis (LAR) is characterized by negative skin testing and serum specific IgE. Diagnosis is based on nasal provocation test (NPT), very sensitive but time-consuming, and/or presence of local synthesis of specific IgE (sIgE) which shows low sensitivity (22\%). The aim of the study was to evaluate the presence of specific D. pteronyssinus (DP) activation of basophils by basophil activation test (BAT) in subjects with confirmed LAR.

\section{Methods}

BAT was performed in 43 subjects: 16 with confirmed LAR (positive NPT with DP, negative skin testing and sIgE to DP), 13 with allergic rhinitis (AR)(positive NPT with DP, positive skin testing and sIgE to DP) and 14 healthy controls (negative NPT, negative skin testing and sIgE to DP). To demonstrate a specific IgE mechanism of basophil activation, BAT with wortmannin pre-treatment was performed in four LAR patients.

\section{Results}

BAT with DP was positive in $85 \%$ of AR patients and $50 \%$ of LAR subjects. BAT showed a substantial correlation with NPT in AR subjects (kappa index: 0.78, $\mathrm{p}=0.0001$ ). The positive responses of the 4 LAR samples that underwent BAT with wortmannin became negative when this substance was added to the assay.

\section{Conclusions}

BAT was able to detect $50 \%$ of LAR subjects to DP, being more sensitive than detection of nasal specific IgE. Responses were IgE-specific demonstrated by BAT-

${ }^{1}$ Carlos Haya Hospital, Allergy Service, Malaga, Spain

Full list of author information is available at the end of the article wortmannin assay. Further studies are needed to test this assay with other allergens.

\section{Author details}

${ }^{1}$ Carlos Haya Hospital, Allergy Service, Malaga, Spain. ${ }^{2}$ Carlos Haya Hospital, Allergy Research Laboratory, Malaga, Spain. ${ }^{3}$ Infanta Leonor Hospital, Allergy Service, Madrid, Spain.

Published: 16 July 2013

doi:10.1186/2045-7022-3-S2-O18

Cite this article as: Campo et al:: Subjects with local allergic rhinitis can be identified by basophil activation test. Clinical and Translational Allergy 2013 3(Suppl 2):018.

\section{Submit your next manuscript to BioMed Central and take full advantage of: \\ - Convenient online submission \\ - Thorough peer review \\ - No space constraints or color figure charges \\ - Immediate publication on acceptance \\ - Inclusion in PubMed, CAS, Scopus and Google Scholar \\ - Research which is freely available for redistribution

